\title{
Chapter 5 \\ Digging Deeper: Deep Wells, Bore-Wells and Water Tankers in Peri-Urban Hyderabad
}

\author{
Nathaniel Dylan Lim and Diganta Das
}

\subsection{Introduction}

Envisioned as a high-tech city and an engine of growth for the region, Hyderabad has enacted a series of economic reforms in the state's economy to attract the likes of foreign investors. In tandem with the city's growing aspirations, rural land spaces are gradually encroached upon and incorporated into the city's planning boundary. Some of these spaces are then gradually transformed into premium infrastructural spaces which consist of countless high-rise gated urban developments which are coupled with the provision of a robust and uninterrupted supply of basic infrastructural services. While the people who reside in these spaces enjoy the benefits that came with economic reforms and premium infrastructural developments, the local urban and peri-urban poor have been simultaneously bypassed (Das, 2015). The basic needs of the poor, such as the inadequate provision of water and power supply, are neglected. Moreover, peri-urban spaces often fall prey to rapid infrastructure developments encroaching into these spaces, being earmarked for future speculative developments. These encroachments have not only affected the livelihoods of the inhabitants living within the spaces but have also exacerbated existing water-related insecurities.

Massive urban restructuring has placed tremendous stress on Hyderabad's water resources. While Hyderabad is home to both natural and human-made water bodies, such as the Musi River and the Hussain Sagar (Ramachandraiah \& Bawa, 2000), the continual expansion of its urban infrastructural developments has led to the encroachment on several water bodies. In particular, the illegal discharge of untreated wastewater has polluted its water bodies and groundwater, rendering them unfit for consumption (Das, 2015; Sen, 2017). Coupled with the growth of massive speculative developments within the city and rising urban population, water demand

N. D. Lim $(\bowtie) \cdot$ D. Das

National Institute of Education, Nanyang Technological University, Singapore, Singapore

e-mail: diganta.das@nie.edu.sg 
has skyrocketed, placing tremendous pressure on its already scarce supply of freshwater (Vij et al., 2019).

These water-related issues are often cited as a consequence of the city's rapid urban development and expansion. However, it is important to go beyond understanding these issues as a product of urban development. Rather, it is about framing our understandings of water within the larger field of urban political ecology, and acknowledging the complex entanglements between nature and society, as well as the complex power-relations in the study of water (Loftus, 2015; Swyngedouw, 2004). Existing literature has delved into various water-related issues, their causes, and impacts on the local inhabitants in Hyderabad. However, our chapter aims to provide a nuanced understanding of these issues by revealing the perspectives of young residents and migrants in the city through their day-to-day interactions with the water they use. Based on ethnographic fieldwork conducted in Hyderabad's urban and peri-urban areas, this chapter intends to delve into the everyday micropolitics of how inhabitants negotiate their water access around existing structures to secure clean water. The following section describes how globalization has shaped cities as engines of growth, in the process leading to urban and peri-urban water insecurity and exacerbating related vulnerabilities. This section is followed by an empirical section based on fieldwork in Hyderabad and its surrounding peri-urban region; we describe the everyday problems of water scarcity in the city and its surroundings, privatization of water and the growing vulnerability of the inhabitants. This section is then followed by the conclusion.

\subsection{Emerging Waterscapes in the Urban and Peri-Urban Global South}

With the advent of modern globalisation, the global economy today is much more interlinked and interdependent than in the past. To tap into this massive network, cities have become the main platform for economic activities, and are becoming more entrepreneurial and outward-looking. They now have an intensifying need to reimage themselves as economic engines and magnets, in order to attract the jobs and investments required to attain the city's aspired economic development goals. As such, cities are in a race to brand themselves as "global", which is defined by Sassen (1991) as having a monopoly of command and control networks and institutions. According to Robinson (2002, p.534), a global city should "be able to articulate regional, national and international economies and serve as prominent nodes of a global economic system". Hence, globalisation is a key process that fuels a city's economic aspirations.

Since the mid-1990s, Hyderabad has been able to tap into these flows and emerged as a node in the global economy by attracting a large amount of foreign investments. This has successfully brought about rapid economic development and, along with it, an unprecedented growth in population through migration. However, 
in the bid to realise its economic and entrepreneurial aspirations to be recognised as an emerging global city, Hyderabad faces several major repercussions on its sociospatial landscape. As Sassen (2005) reminds us, in many cases, cities that are highly integrated into the global economy are more likely to be disconnected from their surrounding areas rather than being able to stimulate territorial assimilation with their regional and national economies. The opening up of the economy and the expansion of Hyderabad have caused the neighbouring peri-urban villages to face many changes, such as large scale real estate development, decrease in agricultural land and increase in water stress (Prakash et al., 2011). Hence, Hyderabad's strategic location in the global network has caused an increase of inequalities between the city and its peripheral areas.

Peri-urban areas are a unique transitional space. Literature has conceptualised this rural-urban interface as a "space" in itself, consisting of highly dynamic interactions between the population and its landscape (Lerner \& Eakin, 2011; Narain, 2010; Prakash et al., 2011). Many researchers have noted that peri-urban areas are frequently contested spaces, which have a growing heterogeneity of interests, and are therefore subjected to potential conflict (Douglas, 2006; Dupont, 2007). As claimants over key resources like land and water gradually multiply, the local natural resource base is impacted. This results in certain environmental and natural resource governance problems that urban or rural governmental or other institutions alone no longer have the ability to cope with (Narain, 2010; see also Lakshmisha et al., 2019).

Hyderabad offers land and basic facilities, such as free or subsidised water supply, to attract private investments and generate further growth (Prakash et al., 2011). As a consequence, the city is experiencing intensifying water shortage; its water table has dropped to such a level that water now has to be sourced from nearby areas outside its municipal boundaries (Prakash et al., 2015). This has brought about inequality in access to water for agriculture and other domestic uses in Hyderabad's peri-urban areas. Villagers are losing out on water access to the more powerful and well-off middle-class population residing in the urban core and to the powerful economic actors involved in peri-urban expansion. Moreover, urban expansion and encroachment into the surrounding transitional areas mostly takes place by encroachment upon forests, pasture commons and agricultural areas. As these are crucial for the natural water cycle, their conversion to urban infrastructure can disrupt this process, negatively affecting the recharging of the groundwater table (Prakash et al., 2011; Vij et al., 2019). Additionally, since these areas now host both agricultural and urban activities, the rise in number of users further contributes to the increase in water stress and insecurity for the villagers.

As the previous sections have established, there has been a depletion of water sources as a consequence of rapid expansion and urbanisation of Hyderabad; the public infrastructure is no longer able to keep pace with the growing needs of the city. Many scholars, including Prakash et al. (2011, 2015), Vij et al. (2019) and Lakshmisha et al. (2019), have documented that, as a result, a large informal groundwater market has emerged over time to bridge the growing gap between supply and 
demand. These informal water suppliers often get their water from sources in periurban regions, which are still richer in surface and groundwater.

Individuals living in the peri-urban areas who used to be farmers helped to fill this market gap by selling water to private tanker companies and small entrepreneurs from urban areas. With the onset of urbanisation, many former agriculturalists have turned away from farming and are taking advantage of the market conditions to sell water to private water tanker companies, who then drive to the water pumps in large trucks and transport the groundwater to customers and industries nearby or in the city (Prakash et al., 2015). This type of business constitutes an informal market, since neither the owners of the water pumps, nor the water tanker companies are registered with any government agency, and thus do not observe any formal guidelines (ibid.). Even though there are laws that regulate the construction of water pumps in most states of India, enforcement remains poor (Araral \& Yu, 2013).

Allen et al. (2006) found that these tankers also supply water to peri-urban households, who have no choice but to pay market prices for water, since the formal supply is incapable of meeting their water needs. The authors distinguish between "policy-driven" and "needs-driven" practices in getting access to water services. They show that in peri-urban areas this access is primarily needs-driven, and that water is obtained through informal means rather than as the outcome of formal policies.

The growing number of users is continually increasing the stress on peri-urban water resources. Incessant exploitation has jeopardized the quantity of water available by negatively impacting the regenerative capacity of the groundwater systems. Water withdrawn far exceeds the amount that is recharged and, according to Prakash et al. (2015), depending on the amount of water that is being extracted, the Central Groundwater Board has listed the groundwater level of several sub-districts that adjoin the city of Hyderabad as critical and over-exploited. As such, groundwater depletion and water insecurity may be seen as both a cause and consequence of the emergence of the informal market; this being an extremely unsustainable cycle.

Rapid urbanisation accompanied by extensive water extraction from peri-urban areas has impacted the local residents' livelihood options. Prakash et al. (2015) observed that for some peri-urban households this has brought about new economic opportunities. There has been a shift in their sources of income, from mainly agricultural activities to more opportunities for employment in the city. As mentioned above, farmers are also taking advantage of the increase in demand for water by participating in the commercial sale of water through extraction of water from their bore-wells, which used to be for agriculture. Selling water to private tankers is a highly attractive option compared to agriculture: it requires little labour and investment but is much more profitable. These options help to diversify household incomes and thus provide households with greater economic security (Narain, 2010).

Vij et al. (2019) see the emergence of the informal water market as a process that has turned water into a tradable commodity, at the cost of the poor and marginalised villagers. Peri-urban areas are now increasingly catering to the water needs of the more well-to-do urban classes, a more prosperous clientele who have the ability to pay for a constant supply of water (Prakash, 2014). As a result, villagers are forced 
to purchase water at the same price. Prakash et al. (2015) observe that the private appropriation of what used to be common pool resources has led to intense local conflicts and water insecurity, as low-income groups have trouble paying for and thus obtaining water on a regular basis. The same research also found that a significant number of households receive less than the basic minimum standard amount of water, while tankers extract up to three times the amount that the village uses for daily household activities. Therefore, such flows of resources from peri-urban to urban areas may offer water security to city dwellers, at the expense of peri-urban residents, who are becoming highly vulnerable and water insecure (Vij et al., 2019).

Due to the informal nature of private water tankers, complaints from the villagers that their groundwater is being extracted for private gains are often to no avail. Most of these private companies operate their water tankers without any legal authorisation (Prakash et al., 2015). The main government body in charge of water issues in Hyderabad, the Hyderabad Metropolitan Water Supply and Sewerage Board, is only concerned with water supply within the city's municipal boundaries, and does not seem to pay any attention to the illegal operations in the peri-urban areas which are outside its purview (ibid). As such, these private tankers are not under the control of any authority and are free to operate as they like. Scholars have also documented that the farmers who are part of this illegal water trading business have the right to sell water as they wish, since groundwater access is tied to landownership through a legal and institutional framework that allows them to do so (Prakash et al., 2011, 2015). Villagers are thus unable to question such practices, which have even become more established due to the lack of a legal body to monitor their activities.

Research by the same authors has shown that peri-urban farmers participating in the commercial sale of water to urban communities are actually unaware of the adverse impacts this has on groundwater (ibid). To them, it is just an alternative livelihood and a way to deal with the dwindling agriculture and economic opportunities in the village. Nevertheless, they are still considered to be the luckier ones who prove resilient to the impacts of encroaching urbanisation and the appropriation of resources from the peri-urban areas. They are able to seize the opportunity for such a profitable activity whereas, the poor and marginalised periurban dwellers are left voiceless, vulnerable and deprived of their basic water supply.

The biophysical and chemical characteristics of water, and the quantification of water flows through the hydrologic cycle are often used as key indicators to determine the severity of water-related issues in Hyderabad. However, solely relying on these indicators as a determinant of these water-related issues treats water as a product of the hydrological cycle, postulating an undisrupted, endless circulation of water devoid of social meaning (Linton \& Budds, 2014). Instead, urban political ecologists such as Swyngedouw (2004) and Loftus (2015) have underscored the inherently political nature of the production and distribution of water among the inhabitants of a city. Water itself embodies not only its biophysical and chemical characteristics $\left(\mathrm{H}_{2} \mathrm{O}\right)$, but also contradictory and inseparable "social, economic, political and cultural processes" (Swyngedouw, 2004, p. 21) which are constantly 
reproduced over time as both a "product and agent of socio-natural change" (Lindon \& Budds, 2014, p. 173, our emphasis). Swyngedouw's (2004) work on the social power of water illustrates this by revealing the political constituents of water that flows through the city. This water that flows is interwoven with the narrative of the state, financial capital, the production of rent, class relations, the process of water purification and the necessity of fulfilling an individual's physiological water needs. Moreover, access to clean urban water in some societies might also carry with it notions of "clarity, cleanliness, health and virginity" (Swyngedouw, 2004, p. 18). While we surface these complex entanglements, it is important that attention is also focused towards the scale of the body. By doing so, this would reveal how waterrelated inequalities are experienced by the inhabitants in their everyday life (Truelove, 2019). This would surface the power dynamics between various individuals and groups, and how this would alter their experiences surrounding water access and use (Sultana, 2009).

\subsection{Methodology}

Ethnographic fieldwork, when applied to research on water security, aims to surface how various socio-cultural and political processes related to water in the broadest sense are experienced, given meaning to and acted upon by people (see also Crang $\&$ Cook, 1995; Spradley, 1980). By doing so, it opens up opportunities to question and trace day-to-day actions and intentions exhibited by people, providing deeper insights on how they make sense of their surroundings (Herbert, 2000). Hence, through the knowledge co-constructed through photographs, interviews and the interactions with our participants, we attempted to interrogate and better understand the meanings and processes embroiled within water use, water access and water security in Hyderabad.

The fieldwork was conducted in December 2019 in Hyderabad, India. During this month, participant observations and semi-structured interviews were conducted in and around the city. The neighbourhoods of Madhapur and Nanakramguda were selected as they reflect the splintered landscapes of Hyderabad; resided by both locals and migrants, low to high income individuals and communities. While the participant observations were conducted along the streets of both neighbourhoods, young people aged 18 to 35 were approached through both random and snowball sampling, and subsequently semi-structured interviews were carried out. As these interviews progressed, some of our respondents allowed us access to their own private living quarters which gave us the opportunity to conduct further observations and discussions. Broadly, our interviews aimed to understand the socio-economic background of our respondents, their perspectives on water-related issues in Hyderabad and their day-to-day routines and interactions with the city's water resources. Subsequently, a thematic analysis on the verbatim interview transcription was done to identify key thematic strands and issues. These themes were 
triangulated with the field notes gathered from the participant observation to further develop on our analyses and identify nuances in our participants' interactions with water.

\subsection{Uneven Landscapes: Differential Water Access and Use in and Around Hyderabad}

\subsubsection{Socio-Spatial Inequalities in the Built Environment}

In transforming the urban landscape of Hyderabad, sprawls of land throughout the city were acquired by various state and private actors for various developments. These spaces, once acquired, are mostly rapidly transformed into various high-rise residential, mixed and office developments which are often occupied by the middleupper social classes - spaces filled with digerati, white-collared office professionals and their families. These high-tech spaces are also premium infrastructural spaces which provide their inhabitants "elite" access to uninterrupted basic services like water supply. While these spaces provide "elite" access to facilities, peripheral spaces are bypassed, leaving behind the urban and rural poor (Das, 2015). While the adjacent peri-urban and rural spaces are now often known as sites of depleting groundwater supply, most urban spaces have the municipality to rely on to provide constant and clean water access to its inhabitants. Despite the municipality's intervention to ensure adequate water supply to these urban spaces, some inhabitants who live within these spaces still do not benefit from these facilities. Specifically, several water-related issues are still prevalent even within the urban built-up area of Cyberabad District.

Located within the financial district of Hyderabad, the neighbourhoods of Nanakramguda and Madhapur in Cyberabad are characterized by sprawls of highrise residential developments and office buildings. Such developments, situated within these premium infrastructural spaces, are well-connected to other parts of the high-tech city through well-paved asphalt roads and concrete sidewalks, and also providing its inhabitants with the provision to uninterrupted access to basic services. While these might represent the modern high-tech business and financial hub that Cyberabad envisions them to be, these spaces are also dotted with landscapes representing the underbelly of the society. In the heart of Nanakramguda, spaces dotted with high-rise developments are lined with adjacent two to three-storey high concrete buildings, rows of zinc-roof houses and unpaved dirt paths in Nanakramguda (Figs. 5.1 and 5.2); a nod to the existing socio-spatial inequalities in Cyberabad. Hence, through our encounters with several inhabitants residing in Nanakramguda and Madhapur, we illustrate how these socio-spatial inequalities manifest through the access to and use of municipal piped tap water, and how its inhabitants negotiate their access to water through these structures. 

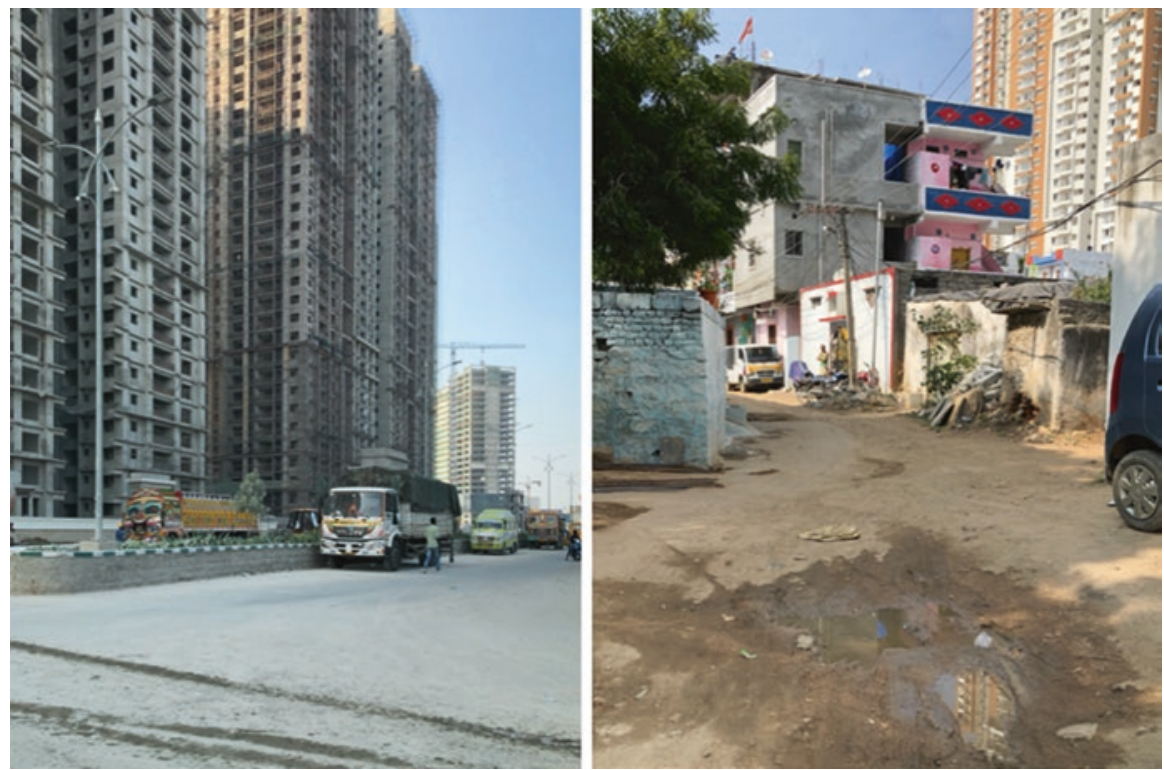

Fig. 5.1 High-rise gated developments (left) and the adjacent neighbourhood (right) in Nanakramguda. (Photos by authors)

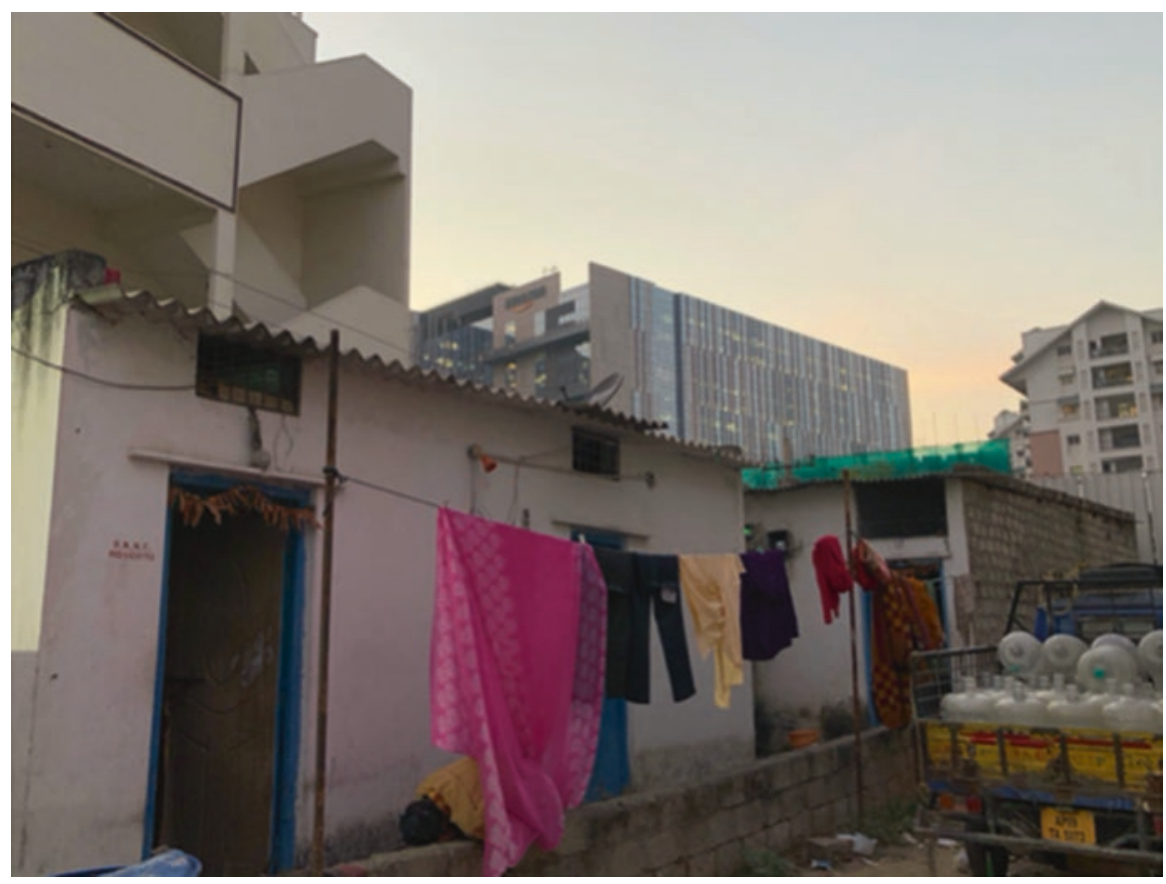

Fig. 5.2 Amazon's headquarters juxtaposed to a low-rise development in Nanakramguda. (Photo by authors) 


\subsubsection{Water as a Splintered Resource}

Premium infrastructural spaces in Cyberabad are known to receive 24-h undisrupted municipal water supply. While connection to piped municipal water infrastructure in Cyberabad District is common, its supply is highly fragmented and disrupted. For households that do not receive municipal tap water, reliance on water from water tankers or bore wells is commonplace, while those who are linked to a piped water system might only receive water supply for a mere 1-2 h every alternate day. In our conversations with the inhabitants living in these areas, they reveal that spaces which are occupied by "professionals" are often provided with premium access. On the other hand, spaces occupied by inhabitants from native villages or holding lowskilled jobs often have to make do with disrupted or otherwise inadequate access to water supply. One migrant, who works as a shop assistant, notes this in our conversation: "What I've heard is that residential area[s], where VIPs (very important persons) used to stay, and in such areas, they get regular water [supply]. In the outskirts, village, low-class people, where they live, they experience water scarcity" (Interview with shop assistant, Hyderabad, 13 December 2019). The mentioning of VIPs points to the fact that these areas of "regular water supply" are commonly associated with people who are able to pay to reside in these spaces (e.g. high-rise gated communities). The spatial fragmentation of water access within an urban area illustrates how water is a highly splintered resource that is brought into the circulation of money and power (Swyngedouw, 2004). In this case, urban water networks in Hyderabad are tied with specific locations and types of accommodation, based on the commodification of water and on practices of granting or limiting access, depending on one's ability to pay for such services.

\subsubsection{Exercising Agency in Attaining Water Access and Use}

Water as a splintered resource in urban Hyderabad places restrictions on the inhabitants' water access. Despite this, inhabitants living in these spaces of limited water access do not succumb to these imposed structures. Rather, what has been observed is a form of individual and collective agency to find ways to secure their own water access and use. Exhibiting agency amid water crises is a common coping response to navigate the politics of water scarcity in the hopes of attaining water security. In poorer urban areas, Das and Skelton (2019) note that obtaining water from self-dug wells, borewells and private water tankers are common practices through which inhabitants try to secure access to water. Similarly, in their ethnographic study on peri-urban communities Narain and Singh (2017) note that inhabitants bypass state restrictions on extracting water from freshwater canals by installing handpumps in the vicinity, to benefit from the higher water table. By exercising various coping strategies, inhabitants circumvent existing structures in an attempt to be more water secure. However, the ways in which they cope with the inherent water insecurity are 
mediated through the intersections of social relations, and their needs and desires. While some inhabitants are able to exercise their agency to attain a more reliable and sustained clean water access and thus attain greater water security, others just find ways to cope in order to reduce the consequences of water insecurity.

In the neighbourhoods of Madhapur it is common for many households to only use the piped municipal tap water for non-consumption purposes (e.g. bathing or household chores). Water that is used for consumption is usually bought, with bottled 20-litre mineral water as a common option. The few households that decide to use tap water for consumption often purify the water, using a store-bought ReverseOsmosis (RO) filter prior to consumption. Generally, households in Madhapur do not consume water directly from the tap. However, in contrast, most households in Nanakramguda use the piped municipal tap water for both consumption and nonconsumption purposes. Only a few households boil the water prior to consumption.

While municipal water is piped to both neighbourhoods, the ways in which the water is used are different. A shop assistant living in Madhapur explains how water is used for households residing in Madhapur: "For drinking water, we will get mineral water from a shop, it is separate from the water which we use for bathing, washing, utensils. The drinking water is very much different, we use mineral water that we purchase". This is not only done in the shop keeper's household, but by many others who are residing in Madhapur. In our conversations, many have attributed this separation between consumable and non-consumable water use to concerns of piped water safety. As such, erring on the side of caution, they have avoided the (direct) consumption of tap water. A building engineer, for instance, aired his doubts about the piped water supply: "It is a safety thing, when the water from the tap is not good $[\ldots]$ sometimes it will have some kind of bacteria. There might be chemicals in the water. In Hyderabad, they also mix some chlorine with water". These people have opted to consume store-bought mineral water to give them an assurance that the water consumed is safe. However, even while mineral water is a popular option in Madhapur, some even cast their doubts on its safety. A research assistant, who resides in a paying-guest residency in Madhapur, expressed her worries in our conversations: "I don't know if it is true, but [I have] heard that sometimes those mineral water bottles are not filled with very clean water. I don't want to fall ill, so it is better that I get an internal [RO filter] system." Water safety is not taken lightly in her instance, even if it means that she has to invest in a good RO filter. Our conversations show that many people have chosen to either purchase bottled mineral water or even purchase an RO filter as an additional safeguard to water safety.

Our conversations with various households in Nanakramguda have revealed a conception of water safety that differs from the situation in Madhapur. Although the households in Nanakramguda receive water from the same municipal supply of water, many households have indicated that the water is safe for direct consumption. However, to ensure that the water does not get contaminated, the households store drinking water in sealed containers or bottles and are kept away from the elements. Conversely, water that is not for consumption are stored in buckets or open water drums (Fig. 5.3). Some households, doubting the safety of tap water, also boil the 

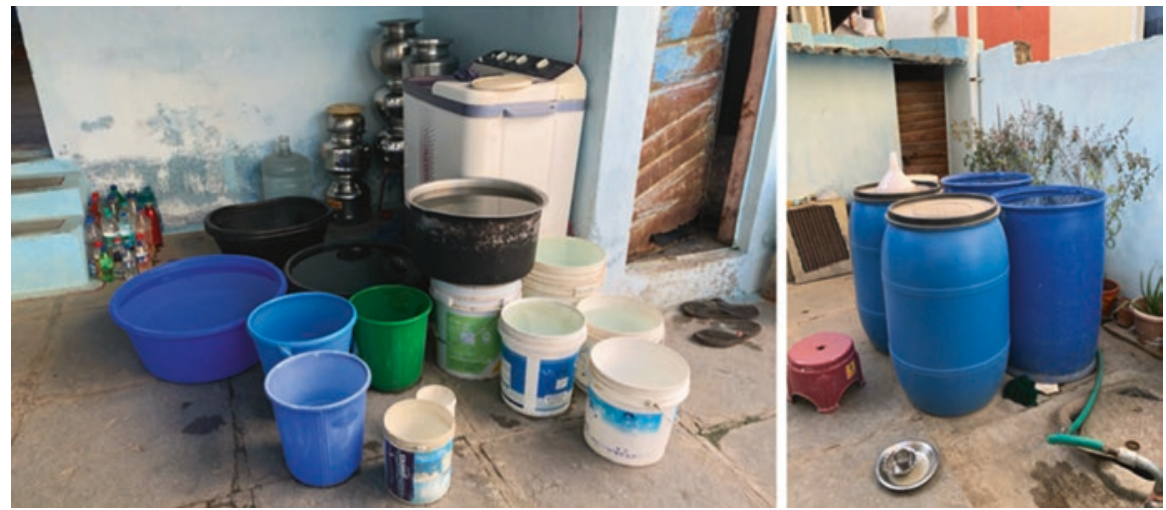

Fig. 5.3 Storage of potable and non-potable water in household. (Photos by authors)

water before consumption and do not purchase mineral water. When asked for the rationale behind their choice, they pointed out that, since the consumption does not result in any ailments, it is safe to drink. Moreover, since they are already paying Rs. 900 per month for the municipal water supply, they do not see the necessity of spending more just for mineral water. One resident of neighbouring Madhapur, empathises with the residents living in Nanakramguda on their choice: "For 10-litres of mineral water, it might take Rs. 30 to Rs. 40, which is costly, especially for a normal person, and the poor. They can't afford it, so they will drink the same water". With limited monetary resources, these inhabitants from lower social classes are often left with limited choices of mediating water insecurity.

While the discourse on water safety largely differs in both neighbourhoods, our conversations with the locals and the ground realities of water use have revealed the fractured nature of water use within Cyberabad. This fracture is largely seen across various social classes and, in particular, the ability of individuals or households to afford mineral or RO-filtered water. The resident of Madhapur mentioned above said that her husband's and her own safety should not be compromised, even if it means paying more for the assurance of clean water: "obviously [consuming RO-filtered water] is incurring more money but safety is something that [I] will not compromise [on]. Since water is scarce in Hyderabad and part of our daily needs, spending a little [more] is alright". As a comparison, the installation of an RO-filter costs an average of Rs. 4500, excluding the costs of maintenance and filter membrane changes amounting to an additional of Rs. 2000 per year. However, mineral water only costs an average of Rs. 15 to Rs. 40 per 20 litres, while the use of tap water does not involve additional costs. The choice to pay more to ensure water safety reflects how water is socially stratified and embroiled within the water/money nexus (Swyngedouw, 2004).

The realities in both neighbourhoods showed that many inhabitants have demonstrated various ways of exercising agency to cope with the lack of clean water supply. However, what is socially stratified are the ways in which the inhabitants cope. 
These ways reflected in the inhabitants day-to-day life, where those who are able to pay for such affordances look towards more formal means (i.e. purchasing mineral water and using an RO-filter), while others, towards more informal means (i.e. covered storage and boiling of water).

\subsubsection{Securing Water Access and Gender-Water Relations}

In urban Hyderabad, intermittent water supply through various neighbourhoods is common. In order for the inhabitants to secure their access to a continual supply of water, many of them have looked to drawing water from borewells, water tankers or storing water from taps in containers (Das \& Skelton, 2019). While the inhabitants have found various ways to cope with the lack of (clean) water supply, our conversations have also revealed that the women in the households, often the wife or the daughter, are often the ones bearing the burden by being the primary "caretaker" of water collection. As such, these women would need to structure their time against water collection timings, bear the physical and mental load of water collection to ensure that the household is water secure. Consequently, the men, unless they live alone, are usually not involved in these duties, as their primary responsibility is to earn an income for the family. However, women, particularly from the lower social classes, are often working hard as well to provide for the family or pay for the education of children, next to their water-related and other household duties.

In one of our interactions with a 19-year old female high-school graduate who resides in Nanakramguda, she shares that she is "responsible" for water collection for her family of three. As the youngest, who is neither working nor studying, she shoulders this responsibility by waking up at six in the morning to store water for her family. In situations where the municipal pipeline ruptures, cutting off water access, she recalls that she would be responsible to obtain water for her family. This is done by either purchasing mineral water or obtaining water from water tankers to ensure sufficient water. Accounts like these, where the woman of the household shoulders water collection duties are commonplace among lower-income families in Hyderabad. Similar to other studies, such as Das and Safini (2018), the gendered division of labour and dependence on their male counterparts to foot for water bills have left women more vulnerable and water insecure in Hyderabad.

While women often bear the brunt of water collection duties in this neighbourhood, an individual's social class can further complicate gender-water relations. In conversations with other women residing in Madhapur, we found that there are two situations where they are not responsible for such duties. In the first case, women do not involve themselves in water collection duties if the household is located within a neighbourhood where there is an undisrupted and clean supply of water. In another case, if the household is located in an area with an interrupted water supply, households with helpers/servants will be responsible for water collection duties. A woman, for instance, living in a family of five explains her household's water collection routine: "My servant will be responsible for storing the water, and 
sometimes, my father who is retired will help her. But, my mother, brother and me are working, so we do not do it" (Interview with secretary, Hyderabad, 13 December 2019).

These two cases further demonstrate how water is embroiled with the notion of power. Whether living in a "premium infrastructural space" with a constant clean water supply or a household with a helper, the ability for a household to pay for such affordances leaves the women of the household free from water collection duties. However, the helper who assumes the water collection duties tends to be a female. The involvement of a female helper is a nod to how class differences are further entwined with gender-water relations. It is also a testament to how these embodied gendered experiences of securing water access not only differs between different households, but also within a household.

\subsection{Conclusion}

The rapid urban expansion in Hyderabad has vastly transformed its landscape to a high-tech metropolis supported by a robust infrastructure system. While these premium infrastructural spaces enjoy the affordances brought by robust state-initiated infrastructure, expansion of the urban community has been at the expense of part of the population residing in the periphery. These marginal peri-urban and urban communities are often bypassed by public services and facilities, suffering from depleting water resources and strained water access. Hence, water in Hyderabad is a highly fractured resource across the intersections of social class and gender.

Still presented as an engine of growth for the region, Hyderabad is not near the end of its conquest for urban expansion. This means that depletion of water resources, privatization of water, splintering of water infrastructure, water contamination and a slew of other water-related issues will probably continue and even exacerbate. However, while the inhabitants of Hyderabad have demonstrated various ways to mediate their access to water, what needs to be brought forth are how these acts, through formal and informal means, remain heavily splintered across social classes. The "water-money nexus" enables inhabitants from middle-upper social classes to attain water security by successfully negotiating their water access amid Hyderabad's water crises, thus creating greater water security for themselves. On the other hand, those inhabitants who are not able to engage in or afford such negotiations can only cope through informal means that often provide less secure access to water, leaving them at an even more precarious position of water insecurity.

Inhabitants themselves are, to a greater or lesser extent, capable of exercising agency to cope in various ways with the lack of access to clean water. Despite this being so, only some are able to successfully negotiate their access to water; hence, many remain water insecure. In the face of rapid urbanisation and exacerbated water-related insecurities, can peri-urban communities find ways to sustainably attain a higher degree of water security for all? 
Acknowledgements We would like to acknowledge the funding support from Nanyang Technological University - URECA Undergraduate Research Programme (IRB-2019-11-022) and NIE AcRF RI 1/17 DKD for this research. We would also like to thank our fieldwork assistants in Hyderabad as well as our NIE Geography BA batchmates (Class of 2020) that helped us during the fieldwork.

\section{References}

Allen, A., Dávila, J. D., \& Hofmann, P. (2006). Governance of water and sanitation Services for the peri-urban poor. A framework for understanding and action in metropolitan regions. Development Planning Unit, UCL.

Araral, E., \& Yu, D. J. (2013). Comparative law, policies, and administration in Asia: Evidence from 17 countries. Water Resources Research, 49, 5307-5316.

Crang, M., \& Cook, I. (1995). Doing ethnographies. Geobooks.

Das, D. (2015). Hyderabad: Visioning, restructuring and making of a high-tech city. Cities, $43,48-58$.

Das, D., \& Safini, H. (2018). Water insecurity in urban India: Looking through a gendered lens on everyday urban living. Environment and Urbanisation ASIA, 9(2), 178-197.

Das, D., \& Skelton, T. (2019). Hydrating Hyderabad: Rapid urbanisation, water scarcity and the difficulties and possibilities of human flourishing. Urban Studies, 1-17.

Dupont, V. (2007). Conflicting stakes and governance in the peripheries of large Indian metropolises-An introduction. Cities, 24, 89-94.

Douglas, I. (2006). Peri-urban ecosystem and societies: Transitional zones and contrasting values. In D. McGregor, D. Simon, \& D. Thomson (Eds.), The peri-urban interface (pp. 18-27). Earthscan.

Herbert, S. (2000). For ethnography. Progress in Human Geography, 24(4), 550-568.

Lakshmisha, A., Priyanka, A., \& Manasi, N. (2019). Assessing the double injustice of climate change and urbanization on water security in Peri-urban areas: Creating citizen-centric scenarios. In Water insecurity and sanitation in Asia (pp. 301-323). Asian Development Bank Institute.

Lerner, A. M., \& Eakin, H. (2011, December). An obsolete dichotomy? Rethinking the ruralurban interface in terms of food security and production in the global south. The Geographical Journal, 177(4), 311-320.

Linton, J., \& Budds, J. (2014). The hydrosocial cycle: Defining and mobilizing a relationaldialectical approach to water. Geoforum, 57, 170-180.

Loftus, A. (2015). Rethinking political ecologies. Third World Quarterly, 30(5), 953-968.

Narain, V. (2010). Peri-urban water security in a context of urbanization and climate change (Peri urban water security discussion paper series, discussion paper no 1: SaciWATERs). Retrieved from http://saciwaters.org/periurban/idrc\%20periurban\%20report.pdf

Narain, V., \& Singh, A. K. (2017). Flowing against the current: The socio-technical mediation of water (in)security in periurban Gurgaon, India. Geoforum, 81, 66-75.

Ramachandraiah, C., \& Bawa, V. K. (2000). Hyderabad in the changing political economy. Journal of Contemporary Asia, 30(4), 562-574.

Prakash, A., Singh, S. and Narain, V. (2011). Changing waterscapes in the periphery: Understanding peri-urban water security in urbanising India. Oxford University Press.

Prakash, A. (2014). The peri-urban water security problem: A case study of Hyderabad in Southern India. Water Policy, 16, 454-469.

Prakash, A., Singh, S., \& Brouwer, L. (2015). Water transfer from Peri-urban to urban areas: Conflict over water for Hyderabad City in South India. Environment and Urbanisation ASIA, $6,41-58$. 
Robinson, J. (2002). Global and world cities: A view from off the map. International Journal of Urban and Regional Research, 26, 531-554.

Sassen, S. (1991). The global city: New York, London, Tokyo. Princeton University Press.

Sassen, S. (2005). The global city: Introducing a concept. Brown Journal of World Affairs.

Sen, S. (2017). Peri urban water woes and development contradictions. Geography and You, $101,74-79$.

Spradley, J. P. (1980). Participant observation. Harcourt Brace Jovanovich College Publishers.

Sultana, F. (2009). Fluid lives: Subjectivities, gender and water in rural Bangladesh. Gender, Space and Culture, 16(4), 427-444.

Swyngedouw, E. (2004). Social power and the urbanisation of water: Flows of power. Oxford University Press.

Truelove, Y. (2019). Rethinking water insecurity, inequality and infrastructure through an embodied urban political ecology. WIREs Water, 6(3), 1-7.

Vij, S., John, A., \& Barua, A. (2019). Whose water? Whose profits? The role of informal water markets in groundwater depletion in peri-urban. Hyderabad.

Open Access This chapter is licensed under the terms of the Creative Commons Attribution 4.0 International License (http://creativecommons.org/licenses/by/4.0/), which permits use, sharing, adaptation, distribution and reproduction in any medium or format, as long as you give appropriate credit to the original author(s) and the source, provide a link to the Creative Commons license and indicate if changes were made.

The images or other third party material in this chapter are included in the chapter's Creative Commons license, unless indicated otherwise in a credit line to the material. If material is not included in the chapter's Creative Commons license and your intended use is not permitted by statutory regulation or exceeds the permitted use, you will need to obtain permission directly from the copyright holder. 